\title{
In vitro antioxidants and antihypertensive properties of corn silk-lemon infusion
}

\author{
Ocheni Ojoma Rabi ${ }^{* *}$ (D) Olufunmilayo Sade Omoba² and Olagunju Aderonke Ibidunni²
}

\begin{abstract}
Background: Agricultural waste generated annually results to environmental pollution; these wastes are rich sources of important bioactive compounds and could be used therapeutically in the management of some ailments. Corn silk, a by-product of sweet corn and whole lemon were processed separately into corn silk flour (CSF) and lemon flour (LF). Flour blends formulation used were as follows: 100\% CSF (A), 95\% CSF and 5\% LF (B), 90\% CSF and 10\% LF (C), 85\% CSF and 15\% LF (D) and 80\% CSF and 20\% LF (E). Chemical compositions of the blends were investigated, while the total phenol content (TPC), total flavonoid contents (TFC), polyphenol profile, antioxidant activities, a-amylase, a-glucosidase inhibitory activities, nitric oxide, L-arginase, Angiotensin-I-Converting Enzyme (ACE) inhibitions as well as the colour and sensory attributes of the infusions were investigated using standard methods.
\end{abstract}

Results: The moisture and total ash contents increased proportionally with increased substitution of LF as moisture content ranged from 4.83 to $8.40 \%$ and the total ash content ranged from 2.32 to $3.25 \%$. The calculated energy values decreased from 390.48 to $361.42 \mathrm{kcal}$, with increase in LF. Potassium (K) contents also increased with values ranging from 4.65 to $5.82 \mathrm{mg} / 100 \mathrm{~g}$, increase in LF incorporation promoted a decrease in the $\mathrm{Na} / \mathrm{K}$ ratio from 0.8 to 0.55 ; the Phy:Ca and Phy:Zn ratios ranged from 1.20 to 2.86 and 2.08 to 4.04, respectively. No significant difference was observed in consumer acceptability but there were total colour differences $(\Delta E)$ in the infusion as compared to the control samples. Samples A and B exhibited notable antioxidant properties, a-amylase, a-glucosidase inhibitory activities, nitric oxide, L-arginase and the ACE inhibitory activities compared favourably with the commercial samples.

Conclusion: This study revealed that corn silk-lemon infusion especially sample A (100\% CSF) may be a therapeutic tool in lowering blood pressure because it possesses potent antihypertensive properties.

Keywords: Anti-nutrients, Antioxidant properties, Mineral composition, Proximate composition, Corn silk and lemon

\section{Background}

Hypertension (high blood pressure), one of the most challenging health problems, is reported to affect 1.13 billion people globally, with women aged $\geq 18$ years accounting for $20 \%$ and men about $24 \%$ in 2015 (Li et al. 2019). Complications of hypertension include heart and renal failure, coronary artery disease and stroke (Hashemipour et al. 2016; Li et al. 2019).

\footnotetext{
*Correspondence: ojomarocheni@gmail.com

${ }^{1}$ Department of Food Science and Technology, Federal Polytechnic, Idah, Nigeria
}

Full list of author information is available at the end of the article
The hormone system that regulates the blood volume plus electrolyte equilibrium is known as renin-angiotensin-aldosterone system (RAAS) which invariably affect pressure of the blood, the vascular tone and resistance. A reduction in renal blood flow activates the kidney to convert the prorenin in the blood into renin and discharge it into circulation. The renin transforms angiotensinogen (formed from the liver) to angiotensin I; an antecedent for angiotensin II (Fountain and Lappin 2021). Angiotensin-I-converting enzyme (ACE) present in the outward of vascular endothelial cells of kidneys and lungs converts angiotensin I to angiotensin II a potent vasoconstrictive peptide in charge of the narrowing of blood vessel and consequently increase blood pressure ( $\mathrm{Li}$ et al. 
2019). Therefore, impeding the activities of ACE would curtail the production of angiotensin II, resulting in the widening of the blood vessels and reduced blood pressure. Several approved medications have been identified as ACE inhibitors; these include captopril, lisinopril and enalapril (Li et al. 2019). Many of these drugs have been reported to adversely affect health upon long time intake (Li et al. 2019) therefore consumption of antioxidant rich food with ACE inhibitory activity might be considered as a potential dietary solution to the menace of high blood pressure.

Corn silk (Maydis stigma "Zea mays hairs"), an agricultural waste from the harvest of sweet corn, is well known for its rich source of antioxidant (Bhuvaneshwari and Sivakami 2015). Study has also shown that corn silk exhibit potassium-induced natriuresis and diuresis ( $\mathrm{Li}$ et al. 2019). Considering its prospective usefulness in the development of nutraceutic products, it may serve as additional source of income to farmers and positively impact their economic livelihood. In another vein, lemon has been reported to possess flavonoids which is responsible for its antioxidative and free radical inhibiting actions, capacity to control enzymatic activities and impede cell propagation (Mohanapriya et al. 2013). A unique component in lemon (potassium) has been connected to the control of blood pressure (Mahendra 2017).

Infusions from herbs are major sources of phenolic compounds with antioxidant and free radical scavenging activities; on this account, they attract recent utilization in foodstuff and pharmaceutical industries. Globally, they represent the largest percentage of consumed drink after water, consequently different herbs or herb combinations serving as therapeutic infusions have been developed. Rodríguez-Vaquero et al. (2014) proposed the use of Argentinean herbs supplemented with lemon juice as prospective natural antioxidants and antihypertensive compounds that may possibly be used in pharmaceutical and food industries; in another study, Ervina et al. (2016) found that some phenolic compounds are the main antioxidant present in Indonesian Cinnamon (Cinnamomum burmannii) bark. Al-Ghafari et al. (2016) studied the influence of lemon additions on the antioxidant activity of tea, while the study of Bhattacharyya et al. (2017) provided a valid evidence to support the existence of a boosting effect between black tea and some supplemented herbs (lemon) used to prepare infusion. Irawaty et al. (2018) reported that corn varieties significantly influence the phytochemical and radical scavenging activities of corn silk, corroborating an earlier report by Ren et al. (2013) on corn silk flavonoids as valuable natural food antioxidants. The aforementioned studies have revealed corn silk as a suitable ingredient in the formulation of functional food. However, there is dearth of information on the antioxidant and antihypertensive activities of infusion prepared from the blend of corn silk and lemon.

\section{Methods \\ Sources of materials \\ Materials}

The corn silk and lemon fruit were both sourced from local farms at Ajaka, Igalamela Odulo Local Government Area of Kogi State, Nigeria.

\section{Chemicals and reagents}

Gallic acid, rutin, quercetin, ascorbic acid, tannic acid, 2,2-diphenyl-1-picrylhydrazyl (DPPH), ferrous sulphate, Ferric chloride $\left(\mathrm{FeCl}_{3}\right)$, Folin-Ciocalteu's phenol reagent, potassium ferricyanide, 2,2'-azino-bis (3-ethylbenzothiazoline-6-sulfonic acid) di-ammonium salt (ABTS) and 6-hydroxy-2,5,7,8-tetramethylchroman-2-carboxylic acid (Trolox) were obtained from Sigma chemical company, USA. All other chemicals and reagents were of analytical grade and were obtained from standard sources.

\section{Processing of food materials Corn silk and lemon flour production}

The corn silk (CS) was processed into flour using the method described by Irawaty et al. (2018) with slight modification. The corn silk was washed with distilled water and oven dried at $50 \pm 2{ }^{\circ} \mathrm{C}$ for $24 \mathrm{~h}$. Similarly, whole lemon fruits were diced, the seeds were removed and the diced fruits were oven dried in a cabinet dryer (Plus11 Sanyo Gallenkamp PLC, UK) at $60 \pm 2{ }^{\circ} \mathrm{C}$ for $24 \mathrm{~h}$. After drying, the corn silk and lemon fruit were milled separately into flour using a Vtcl Excella kitchen mixer grinder (Model BLG 402, Maharashtra, India). The flour samples were separately packed into an airtight plastic container, sealed and stored at $4{ }^{\circ} \mathrm{C}$ until required for use.

Corn silk flour (CSF) and lemon fruit flour (LF) were blended together at blend ratios-100\% CSF (A); 95\% CSF and 5\% LF (B); 90\% CSF and 10\% LF (C); 85\% CSF and $15 \%$ LF (D) and 80\% CSF and 20\% LF (E)] as shown in Table 1 and obtained through a preliminary investigation (details not shown).

\section{Analyses \\ Determination of proximate compositions of corn silk-lemon blend}

The proximate compositions comprising moisture (hot air oven method), crude fat (Soxhlet extraction method), crude protein (Kjeldahl method), total ash (dry ashing) and crude fibre) of corn silk-lemon blends were analysed as described by the standard methods of AOAC (2012). Total carbohydrate $(\mathrm{CHO})$ content was calculated by the difference, as follows: 
Table 1 Formulation of corn silk-lemon blends

\begin{tabular}{lcc}
\hline Sample code & CSF (\%) & LF (\%) \\
\hline A & 100 & 0 \\
B & 95 & 5 \\
C & 90 & 10 \\
D & 85 & 15 \\
E & 80 & 20
\end{tabular}

CSF corn silk flour, LF lemon flour

$$
\begin{aligned}
\mathrm{CHO}(\%)= & 100-(\% \text { Moisture }+\% \text { Total ash }+\% \text { Crude protein } \\
& +\% \text { Crude fat }+\% \text { Crude fibre })
\end{aligned}
$$

The caloric value was calculated as follows using the Atwater factor method previously reported by Osborne and Voogt (1978). The calculation is as follows:

$$
\begin{aligned}
& \text { Energy Value }(\mathrm{Kcal} / 100 \mathrm{~g}) \\
& \begin{array}{l}
=(\text { Crude } \times 4)+(\text { Total carbohydrate } \times 4) \\
\quad+(\text { Crude fat } \times 9)
\end{array}
\end{aligned}
$$

The dry matter was calculated using the formulas previously described (Routa et al. 2018) as follows:

$$
\begin{aligned}
& \mathrm{DMW}_{\mathrm{b}}=\mathrm{TW}_{\mathrm{b}}-\left(\frac{\mathrm{MC}_{\mathrm{b}}}{100}\right) \times \mathrm{TW}_{\mathrm{b}} \\
& \mathrm{DMW}_{\mathrm{C}}=\mathrm{TW}_{\mathrm{C}}-\left(\frac{\mathrm{MC}_{\mathrm{c}}}{100}\right) \times \mathrm{TW}_{\mathrm{C}}
\end{aligned}
$$

Subtracting Eq. (4) from Eq. (3) gives:

$$
\mathrm{DM}=\mathrm{DMW}_{\mathrm{b}}-\mathrm{DMW}_{\mathrm{c}}
$$

Equation (5) is applied for calculation of dry matter of the sample.

Where $\mathrm{DMW}_{\mathrm{b}}$ is the sample initial weight, $\mathrm{DMW}$ is the sample final weight, $\mathrm{DM}$ is the dry matter, $\mathrm{TW}_{\mathrm{b}}$ is the sample initial weight, $\mathrm{TW}_{\mathrm{C}}$ is the sample final weight, $\mathrm{MC}_{\mathrm{b}}$ is the initial moisture content and $\mathrm{MC}_{\mathrm{c}}$ is the final moisture content of sample.

\section{Determination of mineral composition of corn silk-lemon blends}

The mineral composition (calcium, magnesium, iron, copper and zinc) was determined using Atomic Absorption Spectrophotometer (AAS Model SP9). Flame emission photometer (Sherwood Flame Photometer 410, Sherwood Scientific Ltd. Cambridge, UK) was used to determine the sodium and potassium with $\mathrm{NaCl}$ and $\mathrm{KCl}$ as the standards (AOAC 2012).

\section{Determination of anti-nutrient composition of corn silk- lemon blends}

Oxalate content of blends were determined using the method previously described by Day and Underwood (1986). Phytate content of blends were determined using the Wheeler and Ferrel (1971) method. Tannin content was determined using Van-Burden and Robinson (1981) method. Saponin content was determined using the spectrophotometric method described by Brunner (1984).

Calculation of phytate minerals molar ratios of corn silk-lemon blends were calculated from data generated for phytate content and mineral compositions as previously described by Norhaizan and Nor Faizadatul (2009).

\section{Determination of colour attributes of corn silk-lemon infusion}

The colour characteristics of the infusion were determined by a PCE instrument colorimeter. The total colour difference $(\Delta E)$ of samples was calculated using Eq. (7) as follows, previously described by Saricoban and Yilmaz (2010).

$$
\Delta E=\left[\left(L_{\mathrm{o}}-L^{*}\right)^{2}+\left(a_{\mathrm{o}}-a^{*}\right)^{2}+\left(b_{\mathrm{o}}-b^{*}\right)^{2}\right]^{1 / 2}
$$

where $L^{*}, a^{*}$ and $b^{*}$ are the colour parameter values of the infusion and $L_{\mathrm{o}}, a_{\mathrm{o}}$, and $b_{\mathrm{o}}$ are the change in colour parameter values of the infusion.

\section{Sensory evaluations and consumer's acceptability of corn silk-lemon infusion}

Sensory evaluations and consumer's acceptability of the corn silk-lemon Infusion were carried out by 50 (32 males, 18 females) untrained panellist, age range 20-40 years old, consisting of students and staff of the Federal University of Technology Akure, Ondo State and Federal Polytechnic Idah, Kogi State. The samples were evaluated for aroma, taste, colour, flavour and overall acceptance on a 9-point hedonic scale $(1=$ most undesirable and $9=$ most desirable). Significance at $P \leq 0.05$ was observed.

Samples: $100 \%$ CSF (A), 95\% CSF and 5\% LF (B), top tea $(F)$, green tea $(G)$ and lipton tea $(L)$ were used for further studies.

\section{Determination of total phenol, total flavonoids and polyphenol contents of corn silk-lemon infusions}

Total phenol content: The total phenol content of $100 \%$ CSF (A), 95\% CSF and 5\% LF (B), top tea (F), green tea 
(G) and lipton tea (L) were determined using the FolinCiocalteau reaction method of Singleton et al. (1999). Aliquot $(0.2 \mathrm{ml})$ of tea sample was mixed with $2.5 \mathrm{ml}$ of $10 \%$ Folin-Ciocalteu's reagent and $2 \mathrm{ml}$ of $7.5 \%$ sodium carbonate. The reaction mixture will be subsequently incubated at $45{ }^{\circ} \mathrm{C}$ for $40 \mathrm{~min}$, and the absorbance was measured at $700 \mathrm{~nm}$ using UV/VIS spectrophotometer (Shimadzu UV-1700 series; Kyoto, Japan). Gallic acid was used as standard. Gallic acid equivalents (GAE, mg gallic acid/g sample) were used to express the total phenol content.

$$
\begin{aligned}
& \text { Total phenolic content }(\mathrm{mg} \mathrm{GAE} / \mathrm{g}) \\
& =\frac{\text { Abs.sample } \times \text { Conc.standard }(\mathrm{mg} / \mathrm{mL})}{\text { Abs. }{ }_{\text {standard }} \times \text { Conc. } \text { sample }(\mathrm{mg} / \mathrm{g})}
\end{aligned}
$$

Total flavonoid content: determination of the total flavonoid content of $100 \%$ CSF (A), 95\% CSF and 5\% LF (B), top tea $(F)$, green tea $(G)$ and lipton tea (L) using a colorimetric method previously reported by Meda et al. (2005). Aliquot $(0.2 \mathrm{ml})$ of the tea sample was added to $0.3 \mathrm{ml}$ of $5 \% \mathrm{NaNO}_{3}$ at zero time. After $5 \mathrm{~min}, 0.6 \mathrm{ml}$ of $10 \% \mathrm{AlCl}_{3}$ was added and after $6 \mathrm{~min}, 2 \mathrm{ml}$ of $\mathrm{NaOH}$ was added to the mixture followed by the addition of $2.1 \mathrm{ml}$ of distilled water. Absorbance was read at $510 \mathrm{~nm}$ against the reagent blank. Flavonoid content was expressed as quercetin equivalent (QUE).

Identification and quantification of polyphenol compound Total polyphenol content of $100 \%$ CSF (A), 95\% CSF and $5 \%$ LF (B), and top tea (F) was determined. A Shimadzu high-performance liquid chromatographic (HPLC) system (Nexera MX, Maharashtra, India) fitted with $\mu$ Bondapak C18 columns (length $100 \mathrm{~mm}$, diameter $4.6 \mathrm{~mm}$, and thickness $7 \mu \mathrm{m}$ ) was used for the determination. A UV detector (Agilent, 1290 Infinity II High Dynamic Range Diode Array Detector, DAD, Waldbronn, Germany) at $254 \mathrm{~nm}$ was used to detect the compounds while standard solution at a concentration of $1.25 \mathrm{mg} / \mathrm{g}$ was used to measure the retention times of the identified compounds of interest. The infusion was injected into the HPLC (high-performance liquid chromatography) machine to get a curve providing peak area and retention time in a chromatogram. At that juncture, the peak area of the sample was compared with that of the standard relative to the concentration of the standard to get the concentration of the infusions.

\section{Determination of the antioxidant properties of corn silk- lemon infusion}

Evaluation of 2,2-diphenyl-1-picryhydrazyl radical scavenging activity: 2, 2-Diphenyl-1-picryhydrazyl (DPPH) radical scavenging activity of $100 \%$ CSF (A), 95\% CSF and 5\% LF (B), top tea (F), green tea (G) and lipton tea (L) were assessed using Gyamfi et al. (1999) method. Briefly, $1 \mathrm{ml}$ of sample solution was mixed with $1 \mathrm{ml}$ of $0.4 \mathrm{mM}$ methanolic DPPH solution. The resulting mixture was allowed to stand in the dark for $30 \mathrm{~min}$ after which the absorbance was measured at $516 \mathrm{~nm}$. The percentage DPPH scavenging ability was calculated following the equation below:

$$
\begin{aligned}
& \text { DPPH radical scavenging ability (\%) } \\
& =\frac{\text { Abs.ref }- \text { Abs.sample }}{\text { Abs.ref }} \times 100
\end{aligned}
$$

Ferric reducing antioxidant power: The ferric reducing antioxidant power (FRAP) of 100\% CSF (A), 95\% CSF and $5 \%$ LF (B), top tea $(\mathrm{F})$, green tea $(\mathrm{G})$ and lipton tea (L) were assessed as described by Pulido et al. (2000). Exactly $0.25 \mathrm{ml}$ of the liquid sample was mixed with $0.25 \mathrm{ml}$ of $200 \mathrm{mM}$ sodium phosphate buffer ( $\mathrm{pH}$ 6.6) and $0.25 \mathrm{ml}$ of $1 \%$ potassium ferric cyanide (KFC). The mixture was incubated at $50{ }^{\circ} \mathrm{C}$ for $20 \mathrm{~min}$ after which $0.25 \mathrm{ml}$ of $10 \%$ TCA was added and centrifuged (2000 rev per $\mathrm{min} / 10 \mathrm{~min})$. Aliquot $(5 \mathrm{ml}$ ) of the supernatant was mixed with equal volume of distilled water and $1 \mathrm{ml}, 0.1 \%$ $\mathrm{FeCl}_{3}$. Similar treatment was carried out for ascorbic acid solution and the absorbance was measured at $700 \mathrm{~nm}$. The reducing power was calculated and expressed as ascorbic acid equivalent (AAE).

Evaluation of hydroxyl radical scavenging activity:

The antioxidant activity of $100 \%$ CSF (A), 95\% CSF and $5 \%$ LF (B), top tea (F), green tea $(\mathrm{G})$ and lipton tea (L) was evaluated by measuring the hydroxyl $\left(\mathrm{OH}^{\circ}\right)$ radical scavenging ability of corn silk-lemon blend. The ability of the infusions to prevent $\mathrm{Fe}^{2+} / \mathrm{H}_{2} \mathrm{O}_{2}$ induced decomposition of deoxyribose was determined according to the method previously reported by Halliwell et al. (1987). Briefly, $100 \mu \mathrm{l}$ of liquid sample was added to a reaction mixture containing $120 \mu \mathrm{l}, 20 \mathrm{mM}$ deoxyribose, $400 \mu \mathrm{l}$, $0.1 \mathrm{M}$ phosphate buffer $\mathrm{pH} 7.4,40 \mu \mathrm{l}, 20 \mathrm{mM}$ hydrogen peroxide and $40 \mu \mathrm{l}, 500 \mu \mathrm{M} \mathrm{FeSO}$, and the volume was made to $800 \mu \mathrm{l}$ with distilled water. The reaction mixture was incubated at $37{ }^{\circ} \mathrm{C}$ for $30 \mathrm{~min}$ and the reaction was stopped by the addition of $0.5 \mathrm{ml}$ of $2.8 \%$ trichloroacetic acid (TCA); this was followed by the addition of $0.4 \mathrm{ml}$ of $0.6 \%$ thiobarbituric acid (TBA) solution. The tubes were subsequently incubated in boiling water for $20 \mathrm{~min}$. The absorbance was read at $532 \mathrm{~nm}$.

\section{Determination of alpha (a)-amylase and alpha (a)-glucosidase inhibition of corn silk-lemon infusion} Alpha $(\alpha)$-amylase inhibitory activity: Evaluation of alpha $(\alpha)$-amylase inhibition activity of $100 \%$ CSF (A), 95\% CSF and $5 \%$ LF $(B)$, top tea $(F)$, green tea $(G)$ and lipton tea $(\mathrm{L})$ 
were determined using the technique previously reported by Worthington et al. (2003). Absorbance was read at wavelength of $540 \mathrm{~nm}$ while the enzyme inhibitory activity of the infusion was calculated in percentage (\%).

Alpha $(\alpha)$-glucosidase inhibitory activity: Alpha-glucosidase inhibition activity of $100 \%$ CSF (A), 95\% CSF and $5 \%$ LF (B), top tea (F), green tea $(\mathrm{G})$ and lipton tea (L) were determined as previously reported by Apostolidis et al. (2007). The absorbance was read at wavelength $405 \mathrm{~nm}$ with the spectrophotometer while the enzyme inhibitory activity of the infusion was calculated in percentage (\%).

\section{Determination of nitric oxide and L-arginase inhibition activities of corn silk-lemon infusion}

Evaluation of nitric oxide (NO) inhibition activity: The method described by Balakrishnan et al. (2009) was applied to perform the NO radical scavenging assay. The wavelength was measured at the absorbance of $546 \mathrm{~nm}$ with a SpectraMax plus UV-Vis microplate reader (Molecular Devices, GA, USA). The scavenging activity was calculated in percentage.

Evaluation of L-arginase: Arginase inhibition assay of the infusions were performed using the method of Kaysen and Strecker (1973). The optical density was read at $450 \mathrm{~nm}$ after $20 \mathrm{~min}$ and the arginase inhibitory activity was expressed as percentage inhibition.

Angiotensin-I-Converting Enzyme (ACE) Inhibition Assay of corn silk-lemon infusionAngiotensin-I-Converting Enzyme inhibition was assayed by a Spectrophotometric method of Cushman and Cheung (1971). Absorbance was measured at $228 \mathrm{~nm}$ while percentage inhibition was used to express the ACE inhibitory activity.

\section{Statistical analysis}

All determined data were done in triplicates and errors were recorded as standard deviation from the mean (i.e. Mean $\pm S D$ ). Data were then subjected to analysis of variance (ANOVA) using SPSS (IBM version 21.0, USA), while comparison of mean values were further done using New Duncan Multiple Range Test (NDMRT) and values of $\mathrm{p}<0.05$ were considered to be significantly different.

\section{Results}

Proximate composition of Corn silk-lemon blends

Proximate composition of corn silk-lemon blends is presented in Table 2. The moisture contents as well as crude ash contents increased proportionally with increase substitution of lemon flour. Moisture content values ranged from 4.83 to $8.40 \%$, while ash content ranged from 2.32 to $3.25 \%$. Crude protein content of the blends ranged from $12.05 \%$ in sample E to 21.49 in sample A, there is decrease in protein contents with increased lemon flour substitution. The crude fibre contents increased in line with inclusion of lemon, values ranging between 11.91(A) and $21.13 \%$ (E).

The fat and carbohydrate compositions of corn silklemon blends revealed that there were non-significant variations among the samples. Fat contents varied between 9.48 and $11.78 \%$ while carbohydrate contents varied between 51.80 and $54.80 \%$, the energy value ranged from 361.42 (E) to $390.48 \mathrm{kcal} / 100 \mathrm{~g}(\mathrm{~A})$.

\section{Mineral composition of Corn silk-lemon blends}

The mineral contents of the corn silk-lemon blends presented in Table 3. The potassium (K), calcium (Ca) and zinc $(\mathrm{Zn})$ contents increased with increase substitution with lemon flour, values range from 4.65-5.82; $1.56-$ 2.14; $0.16-0.21 \mathrm{mg} / 100 \mathrm{~g}$, respectively. Sodium $(\mathrm{Na})$ and magnesium $(\mathrm{Mg})$ contents decreased with increase in lemon supplementation, as values varied from 3.19$3.74 \mathrm{mg} / 100 \mathrm{~g}$ and $2.53-2.98 \mathrm{mg} / 100 \mathrm{~g}$, respectively. However, the potassium, calcium and zinc contents were significantly higher in sample E compared to other

Table 2 Proximate composition (\%) and energy value of corn silk-lemon blends (dry weight basis)

\begin{tabular}{|c|c|c|c|c|c|c|}
\hline Samples & A & B & $C$ & D & $E$ & Ref* $^{*}$ \\
\hline Moisture & $4.83 \pm 0.25^{c}$ & $6.93 \pm 0.96^{b}$ & $6.73 \pm 0.39^{b}$ & $7.48 \pm 0.46^{\mathrm{ab}}$ & $8.40 \pm 0.42^{a}$ & $<10$ \\
\hline Total ash & $2.32 \pm 0.03^{d}$ & $2.84 \pm 0.05^{c}$ & $3.04 \pm 0.06^{b}$ & $3.18 \pm 0.07^{a b}$ & $3.25 \pm 0.13^{a}$ & $>3$ \\
\hline Crude fat & $9.48 \pm 0.47^{\mathrm{a}}$ & $10.14 \pm 0.26^{a}$ & $11.01 \pm 2.11^{\mathrm{a}}$ & $11.32 \pm 1.27^{\mathrm{a}}$ & $11.78 \pm 0.50^{a}$ & $10-15$ \\
\hline Crude fibre & $11.91 \pm 1.39^{d}$ & $18.00 \pm 0.60^{c}$ & $18.95 \pm 0.32^{b c}$ & $20.29 \pm 0.46^{a b}$ & $21.13 \pm 0.68^{a}$ & $>3$ \\
\hline Crude protein & $21.49 \pm 0.63^{c}$ & $15.03 \pm 0.85^{b c}$ & $14.34 \pm 1.64^{b c}$ & $13.24 \pm 0.22^{b}$ & $12.05 \pm 0.53^{a}$ & $15-28$ \\
\hline Carbohydrate & $54.80 \pm 0.32^{\mathrm{a}}$ & $54.00 \pm 1.65^{\mathrm{a}}$ & $52.66 \pm 3.51^{a}$ & $51.97 \pm 1.89^{\mathrm{a}}$ & $51.80 \pm 0.47^{a}$ & $>64$ \\
\hline Energy (kcal) & $390.48 \pm 7.99^{a}$ & $367.36 \pm 0.86^{b}$ & $367.10 \pm 11.60^{b}$ & $362.70 \pm 4.80^{b}$ & $361.42 \pm 4.73^{b}$ & $>344$ \\
\hline
\end{tabular}

Mean \pm standard deviation of three determinations. Values with different superscripts on a row are significantly different at $p<0.05$ CSF: corn silk flour; LF: lemon flour; A: 100\% CSF; B: 95\% CSF and 5\% LF; C: $90 \%$ CSF and 10\% LF; D: $85 \%$ CSF and 15\% LF; E: 80\% CSF and 20\% LF Ref* FAO (2010) and USDA (2010) Limits 
Table 3 Mineral composition (mg/100 g) of corn silk-lemon blends

\begin{tabular}{|c|c|c|c|c|c|c|}
\hline Mineral elements & A & B & C & D & $\mathrm{E}$ & Ref* $^{*}$ \\
\hline Sodium & $3.74 \pm 0.99^{\mathrm{a}}$ & $3.64 \pm 0.92^{b}$ & $3.44 \pm 0.14^{b}$ & $3.26 \pm 0.26^{c}$ & $3.19 \pm 0.28^{d}$ & 30-134 \\
\hline Potassium & $4.65 \pm 0.85^{c}$ & $5.29 \pm 0.92^{b}$ & $5.28 \pm 1.84^{b}$ & $5.57 \pm 0.92^{\mathrm{ab}}$ & $5.82 \pm 0.14^{\mathrm{a}}$ & $19-502$ \\
\hline Calcium & $1.56 \pm 0.12^{c}$ & $1.80 \pm 0.57^{b}$ & $1.94 \pm 0.01^{b}$ & $1.97 \pm 0.94^{b}$ & $2.14 \pm 0.92^{\mathrm{a}}$ & 19-881 \\
\hline Magnesium & $2.98 \pm 1.04^{\mathrm{a}}$ & $2.56 \pm 1.05^{b}$ & $2.63 \pm 1.25^{b}$ & $2.57 \pm 0.38^{b}$ & $2.53 \pm 0.50^{b}$ & $4.5-452$ \\
\hline Zinc & $0.16 \pm 0.02^{c}$ & $0.16 \pm 0.00^{d}$ & $0.18 \pm 1.0 .02^{c}$ & $0.20 \pm 0.00^{b}$ & $0.21 \pm 0.00^{\mathrm{a}}$ & $0.23-2.1$ \\
\hline Chromium & ND & ND & ND & ND & ND & \\
\hline Lead & ND & ND & ND & ND & ND & \\
\hline $\mathrm{Na} / \mathrm{K}$ & 0.80 & 0.69 & 0.65 & 0.59 & 0.55 & $<1.00$ \\
\hline
\end{tabular}

Mean \pm standard deviation of three determinations. Values with different superscripts on a row are significantly different at $p<0.05$

CSF: corn silk flour; LF: lemon flour; A: 100\% CSF; B: 95\% CSF and 5\% LF; C: $90 \%$ CSF and 10\% LF; D: 85\% CSF and 15\% LF; E: 80\% CSF and 20\% LF. ND: not detected, Ref* FAO (2010) and USDA (2010) limits (mg/day)

samples. The chromium $(\mathrm{Cr})$ and lead $(\mathrm{Pb})$ contents in all the samples were below detectable limit. The sodium/ potassium ratios of blend samples were within the recommended value of $<1.00$.

\section{The anti-nutrient composition of corn silk-lemon blends} The anti-nutrient composition of corn silk-lemon blends is shown in Table 4. Statistically, there were significant $(\mathrm{P}>0.05)$ difference in oxalate contents of the blends examined, the least oxalate value is shown in sample A $(15.83 \mathrm{mg} / 100 \mathrm{~g})$ and highest in sample E $(39.76 \mathrm{mg} / 100 \mathrm{~g})$ followed by sample D with $35.68 \mathrm{mg} / 100 \mathrm{~g}$. Saponin content of the blends ranged from 59.03 to $89.58 \mathrm{mg} / \mathrm{g}$. The highest tannin value was observed in sample A $(6.69 \mathrm{mg} / 100 \mathrm{~g})$ followed by B $(6.56 \mathrm{mg} / 100 \mathrm{~g})$ and the least in sample $\mathrm{E}(3.98 \mathrm{mg} / 100 \mathrm{~g})$. Phytate content varied between 4.23 and $7.35 \mathrm{mg} / \mathrm{g}$.

\section{Colour attributes of corn silk-lemon and commercial tea infusion}

Colour parameter obtained for corn silk-lemon and commercial tea infusion presented in Table 5 . The whiteness ( $L^{*}$ value) of corn silk-lemon blend infusion ranged between 17.50 and 31.37, whereas $a^{*}$-value (red/green) and $b$-values (yellow/blue) varied from 0.60 to 6.64 and 3.22 to 14.95 , respectively. The metric chroma $(C)$, and hue angle $(\mathrm{H})$ had values ranging from $3.39-16.35$ and 66.05-81.25, respectively. Total change in luminosity $\left(\Delta L^{*}\right)$ ranged from -11.43 to -5.89 , change in redness/greenness ( $\Delta a^{*}$ values) varied from 5.25 to 6.04 and change in yellowness/blueness ( $\Delta b^{*}$ values) ranged from 9.57 to 11.72 . Generally, higher values of $\Delta E$ ranging 12.40-18.38 were noted as the overall colour difference in the corn silk-lemon infusion in relation to the control (G) green tea.

\section{Sensory attributes and consumer acceptability of corn silk- lemon and commercial tea infusion \\ All sensory attributes including the overall acceptability were not significantly different $(P>0.05)$ from control except for colour (Table 6). \\ Phenolic distribution and In-vitro antioxidant studies of corn silk-lemon and commercial tea infusion}

Table 7 reveals phenolic distribution (total phenols and total flavonoids) and ferric reducing antioxidant power

Table 4 Anti-nutritional factor $(\mathrm{mg} / \mathrm{g})$ and phytate mineral molar ratio $\left(10^{-3}\right)$ of corn silk-lemon blends

\begin{tabular}{|c|c|c|c|c|c|c|}
\hline Parameters & A & B & $\mathrm{C}$ & $\mathrm{D}$ & $E$ & Standard \\
\hline Phytate & $4.23 \pm 0.15^{c}$ & $4.33 \pm 0.30^{c}$ & $4.23 \pm 0.15^{c}$ & $6.57 \pm 0.03^{b}$ & $7.35 \pm 0.10^{\mathrm{a}}$ & $5-6$ \\
\hline Saponin & $60.42 \pm 18.66^{b}$ & $59.03 \pm 2.95^{b}$ & $61.11 \pm 3.93^{b}$ & $86.11 \pm 3.93^{\mathrm{a}}$ & $89.58 \pm 0.98^{\mathrm{a}}$ & - \\
\hline Tannin & $6.69 \pm 2.91^{\mathrm{a}}$ & $6.56 \pm 0.58^{b}$ & $5.39 \pm 6.11^{c}$ & $5.27 \pm 0.58^{d}$ & $3.98 \pm 3.20^{c}$ & $<30$ \\
\hline Oxalate & $15.83 \pm 0.54^{c}$ & $27.13 \pm 0.35^{d}$ & $32.03 \pm 0.04^{c}$ & $35.68 \pm 0.48^{b}$ & $39.76 \pm 1.07^{\mathrm{a}}$ & $<50$ \\
\hline \multicolumn{7}{|c|}{ Phytate mineral molar $\left(10^{-3}\right)$} \\
\hline Phy:Ca & 1.20 & 1.33 & 1.32 & 2.21 & 2.86 & $<1.56$ \\
\hline Phy:Zn & 2.08 & 2.03 & 2.31 & 4.05 & 4.04 & $<10$ \\
\hline
\end{tabular}

Mean \pm standard deviation for three determinations. Values with different superscripts on a row are significantly different at $p<0.05$ CSF: corn silk flour; LF: lemon flour; A: 100\% CSF; B: 95\% CSF and 5\% LF; C: $90 \%$ CSF and 10\% LF; D: $85 \%$ CSF and 15\% LF; E: 80\% CSF and 20\% LF Ref* FAO (2010) 
(FRAP) in corn silk-lemon infusion. The total flavonoid contents of green tea $(0.35 \mathrm{mg} / \mathrm{g}$ QUE) and total phenolic contents of top tea $(0.53 \mathrm{mg} / \mathrm{g}$ GAE) were higher than values obtained for samples $A$ and $B$ whereas, the total phenol contents in samples A and B compared favourably with the market samples (green tea, top tea and lipton tea). Top tea also exhibited higher FRAP (2.45 mg/g AAE) compared to the other samples.

Some antioxidant properties are shown in Fig. 1A, B. The highest 2, 2-Diphenyl-1-picryhydrazyl (DPPH) free radical scavenging activity was found in $100 \%$ CSF (above $80 \%$ scavenging ability), whereas lipton tea showed the lowest radical scavenging activity. All the corn silk-lemon infusion exhibited high DPPH radical scavenging activity (above 60\%). Lipton tea exhibited the highest inhibitory activity against hydroxyl radicals $\left(\mathrm{OH}^{*}\right)$, higher than $80 \%$ when compared with the other samples. However, all the samples showed high $\mathrm{OH}^{*}$ scavenging activity (above 50\%).

\section{Identification and quantification of phenolic compounds using HPLC-DAD}

HPLC-DAD identified and quantified five phenolic compounds (three flavonoids and two phenolic acids) namely catechin, tannic acid, epigallocatechin, epigallocatechin3-gallate and caffeine in the corn silk-lemon infusion and the control (top tea) as seen in Table 8. Caffeine was the most abundant phenolic compound in sample B with concentration of $2.57 \mathrm{mg} / \mathrm{g}$, whereas the sample showed a low concentration of catechin.

Table 5 Colour attributes of corn silk-lemon and commercial tea infusion

\begin{tabular}{llrlllrrr}
\hline Samples & \multicolumn{1}{l}{ A } & B & C & D & E & F & L & G \\
\hline$L^{*}$ & $23.39 \pm 0.32^{\mathrm{d}}$ & $28.93 \pm 0.20^{\mathrm{b}}$ & $31.37 \pm 0.07^{\mathrm{a}}$ & $24.38 \pm 0.19^{\mathrm{c}}$ & $24.78 \pm 0.04^{\mathrm{c}}$ & $12.36 \pm 0.14^{\mathrm{f}}$ & $6.69 \pm 0.20^{\mathrm{g}}$ & $17.50 \pm 0.45^{\mathrm{e}}$ \\
$a^{*}$ & $1.39 \pm 0.32^{\mathrm{d}}$ & $1.18 \pm 0.02^{\mathrm{d}}$ & $1.25 \pm 0.02^{\mathrm{d}}$ & $1.05 \pm 0.01^{\mathrm{de}}$ & $0.60 \pm 0.00^{\mathrm{e}}$ & $10.54 \pm 0.40^{\mathrm{a}}$ & $8.21 \pm 0.64^{\mathrm{b}}$ & $6.64 \pm 0.07^{\mathrm{c}}$ \\
$b^{*}$ & $5.38 \pm 0.13^{\mathrm{b}}$ & $4.09 \pm 0.13^{\mathrm{c}}$ & $4.16 \pm 0.03^{\mathrm{c}}$ & $3.22 \pm 0.02^{\mathrm{d}}$ & $3.89 \pm 0.01^{\mathrm{c}}$ & $5.56 \pm 0.23^{\mathrm{b}}$ & $2.08 \pm 0.28^{\mathrm{e}}$ & $14.95 \pm 0.24^{\mathrm{a}}$ \\
$C$ & $5.84 \pm 0.70^{\mathrm{d}}$ & $4.26 \pm 0.13^{\mathrm{e}}$ & $4.35 \pm 0.06^{\mathrm{e}}$ & $3.39 \pm 0.02^{\mathrm{f}}$ & $3.94 \pm 0.01^{\mathrm{ef}}$ & $11.92 \pm 0.47^{\mathrm{b}}$ & $8.48 \pm 0.69^{\mathrm{c}}$ & $16.35 \pm 0.19^{\mathrm{a}}$ \\
$H$ & $75.54 \pm 0.14^{\mathrm{b}}$ & $73.83 \pm 0.23^{\mathrm{c}}$ & $73.26 \pm 0.50^{\mathrm{c}}$ & $72.00 \pm 0.16^{\mathrm{d}}$ & $81.25 \pm 0.05^{\mathrm{a}}$ & $27.84 \pm 0.08^{\mathrm{f}}$ & $14.21 \pm 0.83^{\mathrm{g}}$ & $66.05 \pm 0.51^{\mathrm{e}}$ \\
$\Delta E$ & 12.40 & 16.68 & 18.38 & 14.7 & 14.55 & 11.39 & 16.88 & \\
\hline
\end{tabular}

Mean \pm standard deviation for three determinations. Values with the different superscripts on a row are significantly different at $p<0.05$

CSF: corn silk flour; LF: lemon flour; A: 100\% CSF; B: 95\% CSF and 5\% LF; C: $90 \%$ CSF and 10\% LF; D: 85\% CSF and 15\% LF; E: 80\% CSF and 20\% LF; F: top tea; G: green tea; L: Lipton tea

$L^{*}$ : lightness factor; $a^{*}$ : redness factor; $b^{*}$ : yellowness factor; $\Delta E$ : overall differences in colour

Table 6 Sensory attributes and consumer acceptability of corn silk-lemon and commercial tea infusion

\begin{tabular}{|c|c|c|c|c|c|c|c|c|}
\hline Attributes & A & B & C & D & E & $F$ & G & $\mathbf{L}$ \\
\hline Aroma & $7.40 \pm 0.54^{\mathrm{a}}$ & $7.60 \pm 1.34^{\mathrm{a}}$ & $6.40 \pm 1.14^{\mathrm{a}}$ & $6.60 \pm 0.55^{\mathrm{a}}$ & $6.80 \pm 0.84^{\mathrm{a}}$ & $7.80 \pm 0.84^{\mathrm{a}}$ & $7.20 \pm 1.79^{\mathrm{a}}$ & $7.80 \pm 1.30^{\mathrm{a}}$ \\
\hline Taste & $7.60 \pm 0.89^{a}$ & $7.40 \pm 0.89^{\mathrm{a}}$ & $6.80 \pm 1.64^{\mathrm{a}}$ & $7.60 \pm 0.89^{a}$ & $7.20 \pm 1.10^{\mathrm{a}}$ & $7.20 \pm 1.30^{\mathrm{a}}$ & $6.60 \pm 1.82^{\mathrm{a}}$ & $6.80 \pm 1.30^{\mathrm{a}}$ \\
\hline Colour & $7.60 \pm 0.54^{\mathrm{ab}}$ & $7.20 \pm 1.48^{\mathrm{ab}}$ & $7.00 \pm 1.00^{\mathrm{ab}}$ & $7.20 \pm 0.84^{\mathrm{ab}}$ & $6.80 \pm 1.10^{b}$ & $8.00 \pm 1.23^{\mathrm{ab}}$ & $8.40 \pm 0.89^{a}$ & $8.00 \pm 1.00^{\mathrm{ab}}$ \\
\hline Overall acceptability & $3.40 \pm 2.07^{\mathrm{a}}$ & $5.40 \pm 2.88^{\mathrm{a}}$ & $5.20 \pm 2.59^{\mathrm{a}}$ & $5.20 \pm 2.49^{\mathrm{a}}$ & $5.20 \pm 2.59^{\mathrm{a}}$ & $4.20 \pm 2.78^{a}$ & $5.20 \pm 3.03^{\mathrm{a}}$ & $5.40 \pm 2.97^{\mathrm{a}}$ \\
\hline
\end{tabular}

Mean \pm standard deviation for three determinations. Values with different superscripts on a row are significantly different at $p<0.05$

CSF: corn silk flour; LF: lemon flour; A: 100\% CSF; B: 95\% CSF and 5\% LF; C: 90\% CSF and 10\% LF; D: 85\% CSF and 15\% LF; E: 80\% CSF and 20\% LF; F: top tea; G: green tea; L: lipton tea

Table 7 Total flavonoid contents, total phenol and ferric reducing antioxidant power of corn silk-lemon and commercial tea infusion

\begin{tabular}{llllll}
\hline Sample & A & B & F & L & G \\
\hline TFC (mg/g QUE) & $0.22 \pm 0.02^{\mathrm{bc}}$ & $0.16 \pm 0.01^{c}$ & $0.22 \pm 0.01^{\mathrm{bc}}$ & $0.30 \pm 0.04^{\mathrm{ab}}$ & $0.35 \pm 0.07^{\mathrm{a}}$ \\
TPC (mg/g GAE) & $0.32 \pm 0.01^{\mathrm{c}}$ & $0.29 \pm 0.04^{\mathrm{c}}$ & $0.53 \pm 0.03^{\mathrm{a}}$ & $0.38 \pm 0.01^{\mathrm{b}}$ & $0.52 \pm 0.00^{\mathrm{a}}$ \\
FRAP (mg/g AAE) & $1.01 \pm 0.15^{\mathrm{c}}$ & $0.95 \pm 0.05^{\mathrm{c}}$ & $2.45 \pm 0.00^{\mathrm{a}}$ & $0.84 \pm 0.01^{\mathrm{c}}$ & $1.56 \pm 0.06^{\mathrm{b}}$ \\
\hline
\end{tabular}

Mean \pm standard deviation for three determinations. Values with different superscripts on a row are significantly different at $p<0.05$

CSF: corn silk flour; LF: lemon flour; A: 100\% CSF; B: 95\% CSF and 5\% LF; F: top tea; L: lipton tea; G: green tea

TFC: Total flavonoid content; TPC: Total phenolic content; FRAP: Ferric reducing antioxidant power 

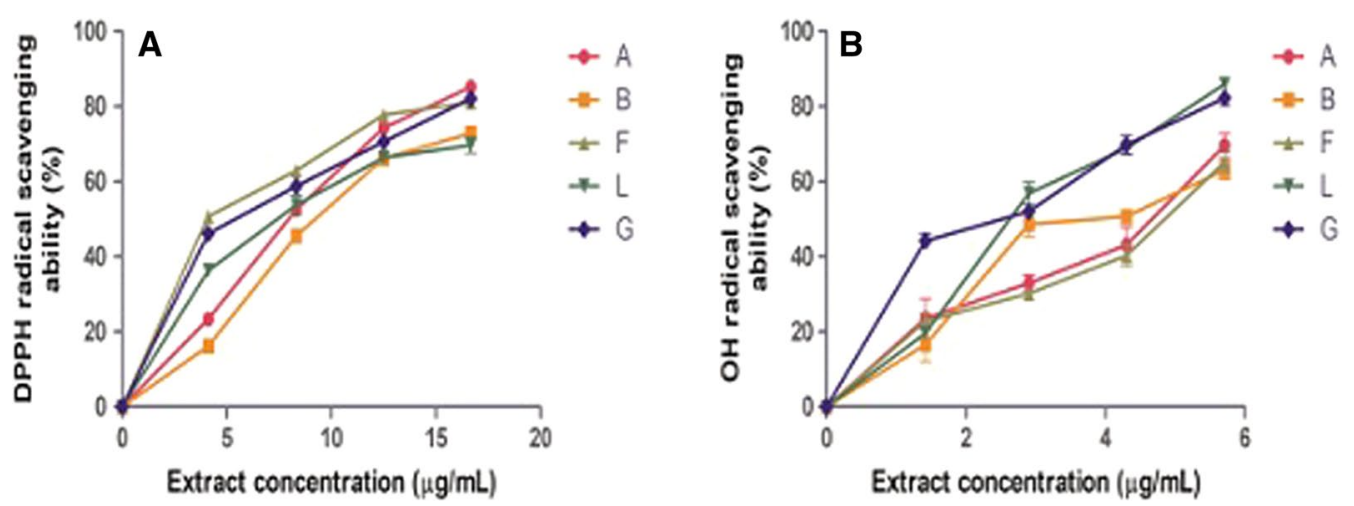

Fig. 1 Antioxidant Activities of corn silk-lemon and commercial tea infusion. A DPPH radical scavenging activities using spectrophotometric method reported by Gyamfi et al. (1999). The absorbance of the mixture prepared from dilution of the infusion and solution containing DPPH radical was read at $516 \mathrm{~nm}$. The percentage DPPH radical scavenging ability of the extracts was calculated as percentage of control. The percent DPPH radical scavenging ability was plotted against five samples extract concentration ( $\mathrm{ug} / \mathrm{ml}$ ). B Hydroxyl radical scavenging activities as described by Halliwell et al. (1987) and tis was used to determine the ability of the extracts to prevent $\mathrm{Fe}_{2+} / \mathrm{H}_{2} \mathrm{O}_{2}$ induced decomposition of deoxyribose. Spectrophotometer was used to take the absorbance reading of the solution prepared from the mixture of the extracts (0-200 $\mu \mathrm{l})$ and reaction mixture. The percent hydroxyl radical scavenging ability was plotted against five samples extract concentration (ug/ml). CSF: corn silk flour; LF: lemon flour; A: 100\% CSF; B: 95\% CSF and 5\% LF; F: top tea; L: lipton tea; G: green tea

Table 8 Identification and quantification of phenolics using HPLC-DAD

\begin{tabular}{llll}
\hline Phenolic compounds & $\mathbf{F}$ & A & B \\
& Conc. (mg/g) & Conc. (mg/g) & Conc. (mg/g) \\
\hline Caffeine $^{\mathrm{a}}$ & 2.27 & 2.31 & 2.57 \\
Catechin $^{\mathrm{b}}$ & 0.22 & 0.33 & 0.35 \\
Tannic acid $^{\mathrm{a}}$ & 0.37 & 0.47 & 0.54 \\
Epigallocatechin $^{\mathrm{b}}$ & 0.40 & 0.40 & 0.62 \\
Epigallocatechin- $^{\text {3-gallate }}$ & 1.65 & 1.89 & 2.23 \\
\hline
\end{tabular}

CSF: corn silk flour; LF: lemon flour; A: 100\% CSF; B: 95\% CSF and 5\% LF; F: Top tea

a Phenolic acids

${ }^{\mathrm{b}}$ Flanvonoids

Alpha (a)-amylase and alpha (a)-glucosidase inhibitory
activity of corn silk-lemon and commercial tea infusion The actions of carbohydrate hydrolyzing enzymes ( $\alpha$-amylase and $\alpha$-glucosidase) were revealed in Fig. 2A, $B$, respectively. Sample A showed very high $\alpha$-amylase inhibitory activity (above 90\%). Sample B and the commercial tea extracts on the hand equally exhibited high inhibitory activity $(<90$ but $>60 \%)$ howbeit, top tea exhibited the least ability to inhibit the $\alpha$-amylase activity (Fig. 2A). Figure 2B showed that green tea demonstrated maximum capacity to inhibit $\alpha$-glucosidase enzyme activity (above 95\% inhibition). Samples A and B compared favourably with the commercial samples (green tea, top tea, lipton tea). All the samples showed high $\alpha$-glucosidase inhibitory activities (> 50\%).

\section{Antihypertensive activities of corn silk-lemon and commercial tea infusion}

The antihypertensive potential of corn silk-lemon and commercial tea infusion shown in Figs. 3A, B and 4 The study revealed that nitric oxide inhibitory activity of sample B was significantly greater than that of sample A. All the infusions showed nitric oxide inhibition activity above $60 \%$ as shown in Fig. 3A. On the other hand, Fig. $3 \mathrm{~B}$ representing arginase inhibition activity by the sample infusion revealed that green tea exhibited the highest inhibitory activity ( $>70 \%$ inhibition) while the other samples exhibited fair inhibitory activities above $50 \%$. Sample A showed the closest arginase inhibition to green tea (higher than 60\%). Sample A, top tea, green tea and lipton tea showed high angiotensin-I-converting enzyme (ACE) inhibition above 60\% (Fig. 4) thus, 100\% CSF infusion compared favourably with commercial tea infusion, whereas sample B showed a fair ability to inhibit ACE (higher than 50\%).

\section{Discussion}

The moisture contents obtained for corn silk-lemon blends were below the suggested moisture content of 10\% for shelf life (FAO 2010; Iwe et al. 2017). It implies that corn silk-lemon blends would be shelf stable since low moisture content decreases biochemical reactions, inhibit mould development and microbial actions in the flour samples.

The increase in ash content as substitution with lemon flour increased may be an indication of high mineral content in lemon fruit. The values obtained 

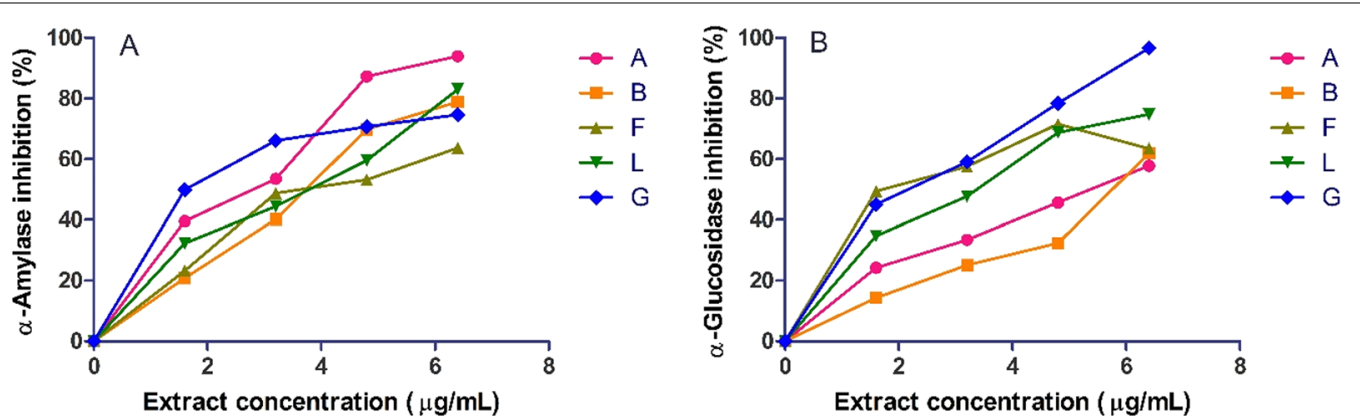

Fig. 2 a-Amylase and a-glucosidase inhibition of corn silk-lemon and commercial tea infusion. A (a)-amylase inhibitory activity. Absorbance of the mixture of infusion dilution, sodium phosphate buffer ( $\mathrm{pH} 6.9$ with $0.006 \mathrm{M} \mathrm{NaCl}$ ) containing Hog pancreatic a-amylase and 1\% starch solution in $0.02 \mathrm{M}$ sodium phosphate buffer ( $\mathrm{pH} 6.9$ with $0.006 \mathrm{M} \mathrm{NaCl}$ ) was read at $540 \mathrm{~nm}$ using a spectrophotometer. The percent a-amylase inhibition was plotted against five samples extract concentration $(\mathrm{ug} / \mathrm{ml})$. The percentage (\%) enzyme inhibitory activity of the phenolic extracts was calculated as described by Worthington et al. (2003). B (a)-glucosidase inhibitory activity: The infusion dilution, a-glucosidase solution, phosphate buffer (pH 6.9). The mixtures were incubated at $25^{\circ} \mathrm{C}$ for $5 \mathrm{~min}$, and absorbance read at $405 \mathrm{~nm}$ in the spectrophotometer. The a-glucosidase inhibitory activity expressed as percentage inhibition and plotted against five samples extract concentration ( $\mathrm{ug} / \mathrm{ml})$. The percentage (\%) enzyme inhibitory activity of the phenolic extracts was calculated (Apostilidis et al. 2007). A: 100\% CSF; B: 95\% CSF and 5\% LF; F: top tea; L: lipton tea; G: green tea; CSF: corn silk flour; LF: lemon flour
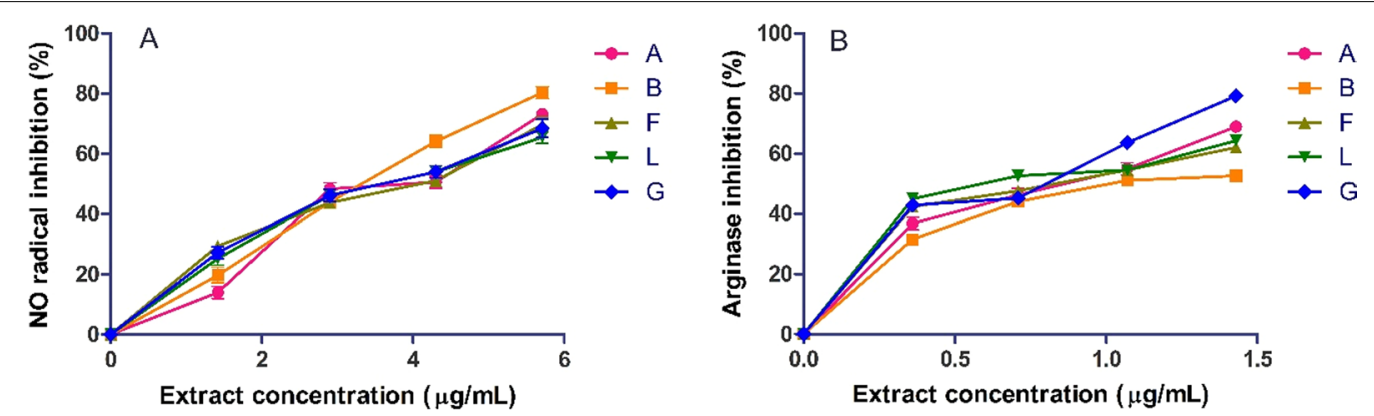

Fig. 3 Nitric oxide and L-arginase inhibitory activities of corn silk-lemon and commercial tea. A Nitric oxide inhibitory activity as described by Balakrishnan et al. (2009). The absorbance of the solution prepared was measured at $546 \mathrm{~nm}$ with a spectraMax plus UV-Vis microplate reader (Molecular Devices, GA, USA). The percentage scavenging was calculated and plotted against five samples extract concentration (ug/ml). B Evaluation of L-arginase. Arginase activity was determined by the measurement of urea produced by the reaction of Ehrlich's reagent. The optical density reading was taken at $450 \mathrm{~nm}$. The control experiment was performed without the test sample and the arginase inhibitory activity was expressed as percentage inhibition and plotted against five samples extract concentration (ug/ml). (Kaysen and Strecker 1973). A: 100\% CSF; B: 95\% CSF and 5\% LF; F: top tea; L: lipton tea; G: green tea; CSF: corn silk flour; LF: lemon flour;

were within the range reported by previous researchers on corn silk and its products (Rosli et al. 2011; Puziah et al. 2012). High ash content is vital since it is involved in digestion of basic biological complexes (Iwe et al. 2017).

Crude protein compositions were comparable to the report by Rosli et al. (2011) and Wan Rosli and Nurhanan (2015) for corn silk flour. The decrease in protein content with increase substitution with lemon flour implies that lemon is low in protein, $(1.10 \%)$ from the report of Mohanapriya et al. (2013).

The increased crude fiber contents may be ascribed to the high composition of crude fiber in lemon. From the report by previous researchers; $15.18 \%$ crude fiber was obtained for lemon peels and $16 \%$ for lemon, respectively (Janati et al. 2012; Mahmood et al. 2019). This implies that the flour blends may be good sources of fibre; fibres have been reported to possess numerous health benefits, including elimination of cancer-causing agent, steroids, bile acids (by binding or engrossing to dietary fiber constituents and excreted speedily), and also lower the menace of cardiovascular disease (Reddy et al. 2017; Akiode et al. 2018). The ranges of crude fiber (11.91-21.13\%) obtained were within the range reported for lemon peels and lemon by Janati et al. (2012) and Mahmood et al. (2019), respectively.

Fat stimulates the absorption of fat-soluble vitamins as such it is very vital in diets (Janati et al. 2012), the fat 


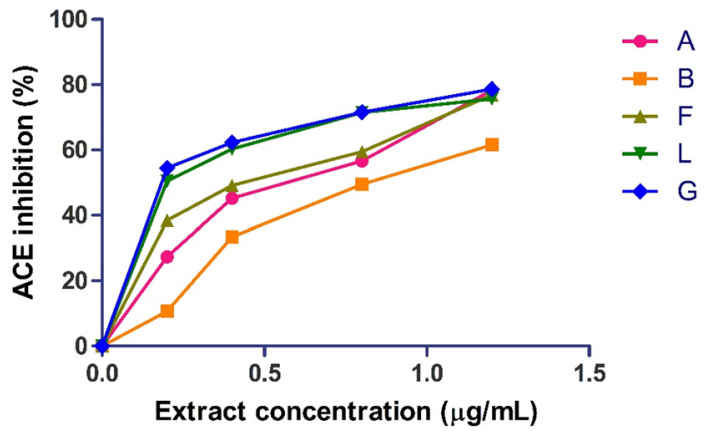

Fig. 4 Angiotensin---converting enzyme (ACE) inhibition of corn silk-lemon and commercial tea infusion. Angiotensin-l-converting enzyme (ACE) inhibition assay in corn silk-lemon and commercial tea infusion by a spectrophotometric method of Cushman and Cheung (1971). The substrate [Hippuryl-histidyl-leucine (Bz-Gly-His-Leu)] and ACE (EC 3.4.15.1) was obtained from rat penile tissue. The amount of cleaved hippuric acid from hippuryl-histidyl-leucine was measured by the enzymatic method. The absorbance of the mixture was measured at $228 \mathrm{~nm}$. The control experiment was performed without the test sample and the ACE inhibitory activity was expressed as percentage inhibition and plotted against five samples extract concentration (ug/ ml). CSF: corn silk flour; LF: lemon flour; A: 100\% CSF; B: 95\% CSF and $5 \%$ LF; F: top tea; L: lipton tea; G: green tea

contents obtained would therefore be of great importance in nutrition. The observed high carbohydrate values obtained implies that the flour blends would be rich sources of carbohydrate. The high energy values recorded suggests the infusion could be a perfect start for the day's activities.

Mehendra (2017) reported that lemon is a rich source of minerals. The high potassium contents of the infusions confirmed the previous findings of Wan Rosli et al. (2010) where potassium was documented as the most abundant electrolyte in corn silk. Potassium is necessary in maintaining the fluid in the body needed to conduct nervous impulse in the system (Zoroddu et al. 2019). Similarly, sodium is a vital electrolyte that helps in the sustenance of the body fluid equilibrium. Involvement of magnesium in the maintenance of the electrical impulse in the nervous system and stimulation of some enzyme systems has been reported by Janati et al. (2012). Therefore, increase in potassium, calcium, magnesium and decrease in sodium intake is connected to a reduction in the level of age-related ailments (Parpia et al. 2018).

Consumption of the infusion, may decrease the sodium level and may be recommended to be suitable for the management of elevated blood pressure and diabetics since less than one sodium/potassium ratio in diet is acclaimed to regulate the blood pressure (Olagunju et al. 2018). The sodium/potassium ratios of blends were within the recommended value of $<1.00$. The non-detection of heavy metals like chromium and lead suggest that the infusions are not toxic when consumed.

Anti-nutrients are compounds that reduce the extensive use of many plants owing to their abundant existences and are capable of stimulating harmful effect in man (Akiode et al. 2018). Values obtained suggests low oxalate content in corn-silk, this is of great benefit because of its undesirable impact on mineral availability. High level of oxalate correlates with increase in calcium absorption in the kidney which can cause kidney stone (Ogunlade et al. 2011).

Tannins are known to form non-soluble compounds with proteins thus decreasing the breakdown of food protein. Phytate is a compound that contains phosphorus which fixes with minerals and impedes the immersion of minerals (Walter et al. 2002). The calculated phytate mineral molar ratio (which are indices for predicting mineral bioavailability) in the flour blends were relatively low when compared to the critical values, which implies that mineral bioavailability may be high in the corn silk-lemon infusion upon consumption (Hassan et al. 2011). This implies less interference of the mineral by the phytate, and thus enhancing the availability of calcium in the system (Walter et al. 2002). The antinutrient composition of the samples in this study were low.

The findings from sensory attributes and consumer acceptability is comparable to the report of Rosli et al. (2011) who revealed non-significance in colour and juiciness of beef patties made from different levels of corn silk. Infusions made from corn silk-lemon blends were comparable to the control (commercial tea).

Colour characteristic of a sample is crucial to the end user because it is linked with freshness and it also controls consumer's choice and likeness (Pathare et al. 2013; Kortei et al. 2015). The values obtained for hue angle (H) were comparable to the values obtained by Kortei et al. (2015). The hue angles obtained for the infusions were close to the $90^{\circ}$, angle of $0^{\circ}$ or $360^{\circ}$ represents red hue, whilst angles of $90^{\circ}, 180^{\circ}$ and $270^{\circ}$ represent yellow, green and blue hues, respectively (Pathare et al. 2013). Total color difference $(\Delta E)$, combines $L^{*}, a^{*}$ and $b^{*}$ values together, the colorimetric parameters are broadly applied to elucidate the dissimilarity in colours (Kortei et al. 2015). $\Delta E$ readings were calculated in relation to green tea (control sample). A larger $\Delta E(\Delta E>3)$ specifies higher colour variation from the reference sample (Saricoban and Yilmaz 2010; Pathare et al. 2013). High values of $\Delta E$ is analytically categorized as very distinct colour differences. The colour of the infusions is very distinct from the control.

Green tea (G) exhibited the highest total flavonoid content which may be attributed to the significant amount of 
catechins present in green tea as previously reported by Rodríguez-Vaquero et al. (2014). Al-Ghafari et al. (2016) also revealed that catechins, the flavanol group of polyphenols is the main bioactive constituents in green tea, and are present in significant quantity, as a result it has great antioxidant potential accountable for its vital biological action with numerous health benefits.

The FRAP assay is directly related to the antioxidant properties of the infusion, this is possibly owing to the proof that polyphenolics with diverse polarities were distributed into the infusions thus increasing their reducing power (Bhattacharyya et al. 2017). Thereby signifying that the phenolic compounds in the infusion displayed the action of electron giver and reduced $\mathrm{Fe}^{3+}$ to $\mathrm{Fe}^{2+}$ (Ademosun et al. 2020).

Herb infusions are significant sources of phenolic compounds, bio functional constituents present in plants and their products, hence engage in human health defensive action. The chemical arrangement and the biological dispersion of the phenolic in the system are accountable for their biological possessions and biological availability (Rodríguez-Vaquero et al. 2014). According to $\mathrm{Hu}$ and Deng (2011), corn silk flavonoids are responsible for the several pharmacological activities exhibited by the infusions.

2, 2-Diphenyl-1-picryhydrazyl free radical inhibition activity is often applied to determine free radical scavenging ability; though it is restricted to colour intrusion and the rate of dilution of the sample (Omoba et al. 2015). The rate of reaction of antioxidant with DPPH is exclusively determined based on the amount of hydroxyl groups present in the polyphenolic antioxidants available (Bhattacharyya et al. 2017). This investigation revealed that corn silk-lemon and commercial tea infusion displayed polyphenols with a high quantity of hydroxyl groups. There is phenolic distribution in plants and there is correlation among phenolic compound and antioxidant potential of certain plants (Omoba et al. 2015; RodríguezVaquero et al. 2014). Vijitha and Saranya (2017) also reported that methanolic extract of corn silk had high DPPH inhibition ability and antioxidative ability which could be as a result of flavonoids, alkaloids, phenols, steroids, glycosides and tannins present in corn silk.

Hydroxyl radical is perhaps the most harmful of free radicals existing in the body (Bhattacharyya et al. 2017). The study revealed that the corn silk-lemon and commercial tea infusions could effectively scavenge hydroxyl radicals and inhibit oxidative damage when consumed.

Caffeine is a vital constituent of tea infusion and is accountable for their unique and desired taste. It is also a potent antioxidant, neutralising reactive oxygen species and improving antioxidant enzyme activity and the glutathione levels. Consistent intake of caffeine can decrease insistent oxidative stress, reducing the occurrence ailments caused by free radicals (Kochman et al. 2021). Furthermore, caffeine can hinder discharge of proinflammatory cytokines, establishing anti-inflammatory properties (Kochman et al. 2021). Corn silk-lemon infusion contains high caffeine content.

The most active compounds of the catechins are epigallocatechin gallate (EGCG), epigallocatechin (EGC), epicatechin gallate (ECG) and epicatechin (Kochman et al. 2021). Epigallocatechin-3-gallate (EGCG) is the most active and abundant of the catechins. Epigallocatechin gallate reduces the susceptibility of an individual to the development of kidney stone (Kochman et al. 2021). It is abundant in the corn silk-lemon infusion which implies that the infusion can effectively prevent kidney stone when regularly consumed.

Diabetes is a chronic, metabolic disease characterized by elevated levels of blood glucose which leads over time to serious damage to the heart, blood vessels, eyes, kidneys and nerves. Diabetes damages the small blood vessels causing stiffening in the walls of the blood vessels thus increases pressure, and invariably leads to high blood pressure. Insulin is the main controller of carbohydrate, fat and protein breakdown, insufficient insulin can disturb the breakdown of the aforementioned (Chelladurai and Chinnachamy 2018). Inhibiting the digestion of carbohydrate to simple sugar and the decline in the quantity of the simple sugar taken into the blood stream is achievable through $\alpha$-amylase and $\alpha$-glucosidase (carbohydrate hydrolyzing enzymes) inhibition, therefore reducing the glycemic indices (GI) as reported by Ademosun et al. (2020). The $\alpha$-amylase converts polysaccharides (two sugar molecule) to the one sugar molecule, whereas $\alpha$-glucosidase (ample in the stomach) breakdown oligosaccharides to one sugar molecule.

Alpha amylase and alpha glucosidase percentage inhibition by corn silk-lemon infusion was presented graphically in Fig. 2A, B. The study revealed that the infusion has higher affinity to inhibit alpha-amylase than alpha-glucosidase. Though the infusion also exhibited high alpha glucosidase inhibition properties at percentage above 50. Inhibition of alpha amylase can lead to decrease in postprandial hyperglycemia (Chelladurai and Chinnachamy 2018). Inhibition of alpha glucosidase causes minimum absorption of monosaccharides. Therefore, the corn silk-lemon and commercial tea infusion can be a vital therapeutic tool to control diabetics via alpha amylase and alpha glucosidase inhibition. This report agrees with previous studies that corn silk extract improves blood sugar level and insulin and it acts on glycaemic metabolic rate through increasing insulin level and mending the injured betacells, respectively (Cha et al. 2016; Vijitha and Saranya 
2017). Also, Tian et al. (2021) documented the effect of the polysaccharides from corn silk on prevention of diabetics.

Arginase is a hydrolase in charge of transformation of L-arginine to urea and L-ornithine. Two arginase exists in vertebrates: type I and type II arginase. Arginase I is a cytoplasmic biocatalyst situated mainly in the glandular organ, while arginase II is situated inside the sarcosome which is highly placed in the nephrons (Bagnost et al. 2010). Nitric oxide creation has reverse link to arginase activities in vessels with biological and uncontrolled disorders like hypertension, diabetics, atherosclerosis etc. Arginase inhibitor prevent the development of high blood pressure through increased NO production ((Bagnost et al. 2010). In this study, corn silk-lemon and infusion exhibited high arginase inhibitory effects which may represent a novel strategy in elevated blood pressure.

Nitric oxide (NO) is a key substance produced by a thin membrane that lines the inside of the heart and blood vessels, phagocyte, neurocyte; it takes part in regulating several biological developments. Nitric oxide is produced in living matters via specific nitric oxide synthase (NOSs) that break down arginine to citrulline alongside the development of NO through an electron reduction response. Too much formation and discharge of NO is linked with some biological disorder (Adebayo et al. 2019). In the process of inflammation, NO is discharged and held constant at elevation position, causing damage to joints, lung and gut. The production and discharge of NO stimulates inflammation; hence, scavenging NO or inhibition of its production, particularly with conforming less cytotoxicity is very important in maintenance of health. The high inhibitory action on NO production as exhibited by the corn silk-lemon and commercial tea infusion is similar to the report of Adebayo et al. (2019) and these supports the anti-oxidative and antidepressant actions of the corn silk-lemon and commercial tea infusion therefore the infusion can act as beneficial nonsynthetic scavengers of inducible nitric oxide synthase (iNOS).

Angiotensin-I-converting enzyme (ACE) play significant role in the development of high blood pressure through renin-angiotensin. Actually, ACE stimulates the transformation of angiotensin I to the strong vasoconstrictor angiotensin II (Nazamid et al. 2015). Angiotensin-I-converting enzyme is recognized for its dual actions to convert inactive angiotensin I to active angiotensin II, and lowers active bradykinin (BK), which plays significant role in regulating blood pressure. The study revealed that corn silk-lemon and commercial tea infusion displayed high ACE inhibitory effect, thereby inhibiting the formation of angiotensin II. This observation is similar to the reports of previous researchers on antihypertensive properties of corn silk (Rodríguez-Vaquero et al. 2014; Li et al. 2019; Vijitha and Saranya 2017). About 10\% increase in ACE inhibitory activity was reported in Argentinean herb infusions with lemon (Rodríguez-Vaquero et al. 2014). Vijitha and Saranya (2017), reported that ACE activity can be curbed by corn silk extract; the beneficial effect of corn silk in lowering blood pressure is exhibited by reducing fluid retention and removing toxins. Li et al. (2019) also documented the existence of peptide in corn silk extract and its negative effects on the development of hypertension.

The study revealed that corn silk-lemon and commercial tea infusion demonstrated high percentage (above $50 \%)$ anti-hypertensive activity through the inhibition of ACE, which is the goal of anti-hypertensive therapeutic pills. Therefore, corn silk-lemon and commercial tea infusion might reduce angiotensin I-induced blood pressure in human.

\section{Conclusions}

Formulated infusions made from corn silk-lemon blends were comparable to the commercial tea (top tea, lipton tea and green tea) in terms of consumer's acceptability. Though there were distinct colour difference from the commercial samples. The infusion also demonstrated important antioxidant ability as shown by their capacity to scavenge free radicals along with their active ferric decreasing potential. The high inhibitory effects of the infusion on $\alpha$-amylase, $\alpha$-glucosidase, nitric oxide, arginase and ACE revealed that the infusion may be beneficial as useful therapeutic infusion in the management of diabetics and hypertension. The findings established that corn silk-lemon and commercial tea infusion is a therapeutic drink especially sample A (100\% CSF) owing to its strong in-vitro antioxidant, in-vitro antihypertensive and in-vitro antidiabetic properties. The helpful and well-being put forth by corn silk-lemon and commercial tea infusion can be associated with the existence of several bioactive substances such as polyphenols, flavonoids and phenols in addition to minerals especially potassium and other important components. Therefore, our findings provided information on the potential use of corn silk-lemon and commercial tea infusion as functional drink in management and prevention of hypertension. In-vivo studies are needed to establish the therapeutic effect and safety of this product.

\footnotetext{
Abbreviations

CS: Corn silk; CSF: Corn silk flour; LF: Lemon flour; A: 100\% CSF; B: 95\% CSF and 5\% LF; C: 90\% CSF and 10\% LF; D: 85\% CSF and 15\% LF; E: 80\% CSF and
} 20\% LF; F: Top tea; L: Lipton tea; G: Green tea; DMW 
$\mathrm{DMW}_{c}$ : Final weight of sample; $\mathrm{DM}$ : Dry matter; $\mathrm{MC}_{\mathrm{b}}$ : Initial moisture content of the sample; MCc: Final moisture content of the sample; Eqn: Equation; TFC Total flavonoid content; TPC: Total phenolic content; FRAP: Ferric reducing antioxidant power; ACE: Angiotensin---converting enzyme; RAAS: Reninangiotensin-aldosterone system; DPPH: 1,1-Diphenyl-2-picryl-hydrazyl; ABTS 2,2-Azinobis [3ethylbenzothiazoline-6-sulfonic acid] di-ammonium salt; HAT: Hydrogen atom transfer; ET: Electron transfer; OAC: Oxygen absorbance capacity; ORAC: Oxygen radical absorbance capacity; TRAP: Total radical trapping antioxidant parameter; TOSC: Total oxidant scavenging capacity; NO: Nitric oxide; NOS: Nitric oxide synthase; CGMP: Cyclicguanosine monophosphate; eNOS: Endothelial nitric oxide synthase; NADPH: Nicotinamide adenine dinucleotide phosphate; SGC: Soluble guanylylcyclase; FP: Flame photometer; AAS: Atomic absorption spectroscopy; HPLC: High-performance liquid chromatographic; EGCG: Epigallocatechin gallate; EGC: Epigallocatechin; ECG: Epicatechin gallate; FCS: Corn silk flavonoids; ACEl: Angiotensin converting enzyme inhibitory; ROS: Reactive oxygen species; iNOS: Inducible nitric oxide synthase.

\section{Acknowledgements}

The author will like to acknowledge staff of Functional Food Laboratory and Food Science and Technology laboratory of The Federal University of Technology Akure, Nigeria.

\section{Authors' contributions}

ORO carried out the laboratory analysis and wrote the first draft of the manuscript while OSO conceptualize the research, supervised the study and proof read the first draft. OAl supervised the study, read and corrected the manuscript. All the authors read and approved the final manuscript.

\section{Funding}

No funding was received for this research work.

\section{Availability of data and materials}

Data are available on request.

\section{Declarations}

\section{Ethics approval and consent to participate}

The study protocol was approved by the Ethical Committee School of Agriculture and Agricultural Technology, Federal University of Technology, Akure, Nigeria (FUTA/SAAT/2020/016). Verbal agreement to participate was obtained from the sensory panelists that participated in sensory evaluation.

\section{Consent for publication}

Not applicable.

\section{Competing interests}

The authors declare that they have no competing interests.

\section{Author details}

'Department of Food Science and Technology, Federal Polytechnic, Idah, Nigeria. ${ }^{2}$ Department of Food Science and Technology, Federal University of Technology, Akure, Nigeria.

Received: 17 December 2021 Accepted: 11 February 2022 Published online: 3 March 2022

\section{References}

Adebayo SA, Ondua M, Shai L, Lebelo SL (2019) Inhibition of nitric oxide production and free radical scavenging activities of four South African medicinal plants. J Inflamm Res 12:195-203

Ademosun MT, Omoba OS, Olagunju Al (2020) Antioxidant properties, glycemic indices, and carbohydrate hydrolyzing enzymes activities of formulated ginger-based fruit drinks. J Food Biochem. https://doi.org/10. $1111 / \mathrm{jfbc} .13324$

Akiode SO, Fadeyi AE, Falayi OE, Emmanuel SA, Onyenekwe PC (2018) Nutrients, phytochemical composition and antioxidant analysis of selected agricultural wastes as potential livestock feed ingredients. NJBAS 26(2):35-44

Al-Ghafari AB, Shorbaji AM, Al-Sarori LA, Baduwailan EO, Basaar AA, AlDoghaither HA, Al-Marzouki HF, Omar UM (2016) Phenolic contents and antioxidant activities of green tea with and without lemon. J Nat Sci 8:247-255

AOAC (2012) Official methods of analysis of the association of official analytical chemists (AOAC) international, 18th edn. AOAC

Apostilidis E, Kwon YII, Setty K (2007) Inhibitory potential of herb, fruit, and fungal-enriched cheese against key enzymes linked to type 2 diabetes and hypertension. Inn Food Sci Emerg Technol 8:46-54

Bagnost T, Ma L, Silva RF, Rezakhaniha R, Houdayer C, Stergiopulos N, Andre C, Guillaume Y, Berthelot A, Demougeot C (2010) Cardiovascular effects of arginase inhibition in spontaneously hypertensive rats with fully developed hypertension. Cardiovasc Res 87(3):569-577

Balakrishnan N, Panda AB, Raj NR, Shrivastava A, Prathani R (2009) The evaluation of nitric oxide scavenging activity of Acalypha indica linn root. Asian J Chem 2(2):148-150

Bhattacharyya S, Chakrabartia G, Bhattacharjeea S (2017) Evaluation of antioxidant profile and phytochemical constituents of some herb-supplemented black tea infusions. Int J Pharm Sci 9(12):131-135

Bhuvaneshwari K, Sivakami S (2015) Analysis of nutrients and phytochemicals content in corn silk (Zea mays). IJSR 6:79-81

Brunner JH (1984) Direct spectophotometer determination of saponin. Anal Chem 34:134-136

Cha JH, Kim SR, Kang HJ, Kim MH, Ha AW, Kim WK (2016) Corn silk extract improves cholesterol metabolism in C57BL/6J mouse fed high-fat diets. Nutr Res Pract 4:1457-1476

Chelladurai GRM, Chinnachamy C (2018) Alpha amylase and Alpha glucosidase inhibitory effects of aqueous stem extract of Salacia oblonga and its GC-MS analysis. Braz J Pharm Sci 54(1):e17151

Cushman DW, Cheung HS (1971) Spectrophotometric assay and properties of the angiotensin---converting enzyme of rabbit lung. Biochem Pharmacol 20:1637-1648

Day RA, Underwood AL (1986) Qualitative analysis, 5th edn. Prentice Hall Publication, $\mathrm{p} 701$

Ervina M, Nawu YE, Esar SY (2016) Comparison of in vitro antioxidant activity of infusion, extract and fractions of Indonesian Cinnamon (Cinnamomum burmannii) bark. Int Food Res J 23(3):1346-1350

Food and Agricultural Organization-FAO (2010) Nutritional elements of Food and Agricultural Organization. FAO

Fountain JH, Lappin SL (2021) Physiology, renin angiotensin system. StatPearls Publishing

Gyamfi MA, Yonamine M, Aniya Y (1999) Free radical scavenging action of medicinal herbs from Ghana Thonningia sanguinea on experimentally induced liver injuries. Gen Pharmacol Vasc Syst 32:661-667

Halliwell B, Gutteridge JM, Aruoma OI (1987) The deoxyribose method: a simple "test-tube" assay for determination of rate constants for reactions of hydroxyl radicals. Anal Biochem 165(1):215-219

Hashemipour M, Kargar M, Ghannadi A, Kelishadi R (2016) The effect of citrus Aurantifolia (lemon) peels on cardiometabolic risk factors and markers of endothelial function in adolescents with excess weight: a triple-masked randomized controlled trial. Med J Islam Repub Iran 429(30):1-7

Hassan LG, Umar KJ, Dangoggo SM, Maigandi AS (2011) Anti-nutrient composition and bioavailability prediction as exemplified by calcium, iron and zinc in Melocia corchorifolia leaves. Pak J Nutr 10(1):23-28

Hu Q, Deng Z (2011) Protective effects of flavonoids from corn silk on oxidative stress induced by exhaustive exercise in mice. J Afri Biotechnol 10(16):3163-3167

Irawaty W, Ayucitra A, Indraswati N (2018) Radical scavenging activity of various extracts and varieties of corn silk. J ARPN Eng Appl Sci 13(1):10-14

Iwe MO, Micheal N, Madu NE, Obasi NE, Onwuka GI (2017) Physicochemical and pasting properties of high-quality cassava flour (HQCF) and wheat flour blends. Agrotechnology 3(6):1-8

Janati SSF, Beheshti HR, Feizy J, Fahim NK (2012) Chemical composition of lemon (Citrus Limon) and peels its considerations as animal food. GIDA 37(15):267-271

Kaysen GA, Strecker HJ (1973) Purification and properties of arginase of rat kidney. Biochem J 133(4):779-788 
Kochman J, Jakubczyk K, Antoniewicz J, Mruk H, Janda K (2021) Health benefits and chemical composition of Matcha green tea: a review. Molecules 26(1):85

Kortei NK, George GT, Obodai M, Appiah V, Akonor PT (2015) Determination of color parameters of gamma irradiated fresh and dried mushrooms during storage. Croat J Food Technol Biotechnol Nutr 10(1-2):66-71

Li C, Lee Y, Lo H, Huang Y, Hsiang C (2019) Antihypertensive effects of corn silk extract and its novel bioactive constituent in spontaneously hypertensive rats: the involvement of angiotensin-converting enzyme inhibition. J Mol 24:1-14

Mahendra P (2017) Lemon: a versatile fruit of multiple uses. Agriculture World, pp 52-54

Mahmood S, Iqra IS, Ranjhda MMA, Shahzad JK, Jaangla KT, Masood AB, Mustafa S (2019) A critical review on nutritional and medicinal importance of lemon. Acta Sci Agric 3(6):95-97

Meda A, Lamien CE, Romito M, Millogo J, Nacoulma OG (2005) Determination of the total phenolic, flavonoid and proline contents in Burkina Faso honey, as well as their radical scavenging activity. Food Chem 91:571-577

Mohanapriya M, Ramaswamy L, Rajendran R (2013) Health and medicinal properties of lemon (Citrus limonum). Int J Ayurvedic Herb 3(1):1095-1100

Nazamid S, Ghanbari R, Zarei M, Ebrahimpour A, Abdul-Hamid A, Ismail A (2015) Angiotensin-I converting enzyme (ACE) inhibitory and antioxidant activities of sea cucumber (Actinopyga lecanora) hydrolysates. Int J Mol Sci 16:28870-28885

Norhaizan M, NorFaizadatul AW (2009) Determination of phytate, iron, zinc calcium contents and their molar ratios in commonly used raw and prepared food in Malaysia. Malays J Nutr 15(2):213-222

Ogunlade I, liugbiyin A, Osasona Al (2011) A comparative study of proximate composition, antinutrient composition and functional properties of Pachira glabra and Afzelia Africana seed flours. Afr J Food Sci 5(1):32-35

Olagunju Al, Omoba OS, Enujiugha VN, Aluko RE (2018) Development of value-added nutritious crackers with high antidiabetic properties from blends of Acha (Digitaria exilis) and blanched Pigeon pea (Cajanus cajan). Food Sci Nutr 6:1791-1802

Omoba OS, Obafaye OR, Salawu SO, Boligon AA, Athayde LM (2015) HPLCDAD phenolic characterization and antioxidant activities of ripe and unripe sweet orange peels. Antioxidants 4:498-512

Osborne DR, Voogt PI (1978) The analysis of nutrients in foods. Academic Press Inc

Parpia AS, Darling PB, L'Abbe MR, Goldstein MB, Arcand J, Cope A, Shaikh AS (2018) The accuracy of Canadian nutrient file data for reporting, potassium, sodium, and protein in selected meat, poultry, and fish products. Can J Public Health 109(1):150-152

Pathare PB, Opara UL, Al-Julanda A-S (2013) Colour measurement and analysis in fresh and processed foods. Food Bioprocess Technol 6:36-60

Pulido R, Bravo L, Saura-Calixto F (2000) Antioxidant activity of dietary polyphenols as determined by a modified ferric reducing/antioxidant power assay. J Agric Food Chem 48:3396-3402

Puziah H, Hasanudin K, Mustafa S (2012) Corn silk (Stigma maydis) in healthcare: a phytochemical and pharmacological review. J Mol 17:9697-9715

Reddy KR, Madhu C, Krishna KM, Lakshmi PJ, Kelari EK (2017) Estimation of crude fiber content from natural and food stuffs and its laxative activity induced in rats. Int J Pharma Res Health Sci 5(3):1703-1706

Ren SC, Qiao QQ, Ding XL (2013) Antioxidative activity of five flavones glycosides from corn silk (Stigma maydis). Czech J. Food Sci 31(2):148-155

Rodríguez-Vaquero MJ, Claudia VV, Aredes-Fernandez PA (2014) Biological activity of phenolic compounds from Argentinean herbs infusions. Open Conf Proc J 5:1-7

Routa J, Kolström M, Sikanen L (2018) Dry matter losses and their economic significance in forest energy procurement. Int J Eng 29(1):53-62

Saricoban C, Yilmaz MT (2010) Modelling the effects of processing factors on the changes in colour parameters of cooked meatballs using response surface methodology. World Appl Sci J 9(1):14-22

Singleton VL, Orthofer R, Lammela-Raventos M (1999) Analysis of total phenols and other oxidation substrates and antioxidant by means of Folin-Ciocalteu reagent. Methods Enzymol 299:15-178

Tian S, Sun Y, Chen Z (2021) Extraction of flavonoids from corn silk and biological activities in-vitro. J Food Qual 2021:1-9
USDA (2010) United State Department of Agriculture, Agricultural Research Service, National Nutrition Data base for standard reference. Release, 23, Nutrition Laboratory (2010)

Van-Burden TP, Robinson EC (1981) Formation of complexes between proteins and tannin acid. J Agric Food Chem 1:77-82

Vijitha TP, Saranya D (2017) Corn silk—a medicinal boon. Int J ChemTech Res 10(10):129-137

Walter HL, Fanny L, Charles C, Christian R (2002) Minerals and phytic acid interaction: is it a real problem for human nutrition. Int J Food Sci 37:727-739

Wan Rosli WI, Nurhanan RA (2015) Cornsilk as an alternate functional ingredient. Wr_hanan's 13:267-285

Wan Rosli WI, Nurhanan AR, Farid CG, Mohsin SSJ (2010) Effect of sodium hydroxide $(\mathrm{NaOH})$ and sodium hypochlorite $(\mathrm{NaHClO})$ on morphology and mineral concentration of Zea mays hairs (corn silk). Ann Microsc 10:4-10

Wan Rosli WI, Nurhanan AR, Solihah MA, Mohsin SSJ (2011) Corn silk improves nutrient content and physical characteristics of beef patties. Sains Malays 40(2):155-161

Wheeler EL, Ferrel RE (1971) A method for phytic acid determination in wheat and wheat fraction. Cereal Chem 48:312-316

Worthington P, Hoang V, Perez-Pomares F, Blum P (2003) Targeted disruption of the a-amylase gene in the hyperthermophilic archaeon Sulfolobus solfataricus. J Bacteriol 185(2):482-488

Zoroddu MA, Aaseth J, Crisponi G, Medici S, Peana M, Nurchi VM (2019) The essential metals for humans: a brief overview. J Inorg Biochem 195:120-129

\section{Publisher's Note}

Springer Nature remains neutral with regard to jurisdictional claims in published maps and institutional affiliations.

\section{Submit your manuscript to a SpringerOpen ${ }^{\circ}$ journal and benefit from:}

- Convenient online submission

- Rigorous peer review

- Open access: articles freely available online

- High visibility within the field

- Retaining the copyright to your article

Submit your next manuscript at $\boldsymbol{\nabla}$ springeropen.com 